\title{
The issue of social situation of homosexual women as potential for using eclectic research
}

\section{KEYWORDS}

eclectic research, LGBTQIA, homosexual women, social situation

\begin{abstract}
Scientists practicing social sciences issues more and more often undertake constructing and performing eclectic research projects. Nowadays, qualitative and quantitative approaches are thought to be equivalent. Their results can be characterized by complementarity, facilitation and/or triangulation.

The article presents two research papers - quantitative which is represented by a report titled 'Social situation of LGBTA people in Poland. Report 2015-2016' written by organizations supporting LGBTQIA environments - and quantitative master thesis titled 'The quality of life of homosexual women - cases study'. These projects arose in similar time, but they were developed and conducted independently. Compared results are connected to issues of functioning of homosexual women in a range of identical or approximate categories of both studies.

The main aim of the article is to show the validity of quantitative and qualitative trends connection on the example of presented papers - despite of distinctiveness of these two conceptions their results illustrate each other in many questions. The quantitative publication pictures the scale of the phenomenon while the qualitative one gives the context of gathered data. In presented text it is shown not only how the results complement one another, but also how they mutually verify and give a possibility to widen the cafeteria of dependent variables or categories of thematic-notions frame.

The secondary aim of the paper is to outline the problematic aspects of functioning of homosexual women in environments and social groups to which they belong. The article is rich in references that discusses in details mentioned issues; these are: an attitude toward public institutions and
\end{abstract}


politics in Poland, conditions of sexual orientation openness, professional, family and social relations, same-sex relationships and a violence motivated by prejudices.

The awareness of benefits from using the eclectic approach in examining social phenomena can arise the cognitive value of research projects and as an effect increase effectiveness of actions in favour of nonheteronormative individuals.

Adam Mickiewicz University Press, pp. 115-132

ISSN 2300-0422. DOI 10.14746/kse.2019.15.8

ORCID: https://orcid.org/0000-0001-8199-6716

\section{Introduction}

The essence of research problems generates a reflection on a nature of research project which by using its methods lets comprehensively answer gathered questions (Flick, 2012: 30-32). Qualitative and quantitative approaches, once treated as oppositional, nowadays are thought to be complementary. Therefore, a two-dimensional consideration of a research problem becomes a common practice both from the perspective of particular phenomenon's scale and from the field of individual stories that take part inside it.

In the subject literature there are suggestions relating to the connection between qualitative and quantitative approaches. Martyn Hammersley (2013: 11-12) shows three ways of such solution and adds that there can be more of them. Those mentioned by him are:

- triangulation: research results of both paradigms let check each other;

- facilitation: studies conducted in one trend bring hypothesis and inspirations that can be used in an another research approach;

- complementarity: qualitative and quantitative trends complement each other and give wider description of studied issue.

The question of a qualitative results representativeness requires a theoretical examination. Generalization of that kind of data obligates to reject the context in which researched case is implanted and to wonder in which different contexts extrapolated theory keeps the condition of accuracy (Flick, 2011: 194-195). Such generalization will not have the statistical nature but it will receive a semantic character (cited in Staś-Romanowska, 2010: 104). What is more, qualitative and quantitative results linking favours the defining of qualitative results representativeness (Silverman, 2012: 269-276).

Handed article poses a presentation of two scientific papers that are implanted in different methodologies but have similar aims and questions about the condi- 
tion of interesting phenomena. Relating to ways of connecting research perspectives that are presented above, it must be noticed that those papers are complementary in a specific way (despite they were written independently) and among them one can use triangulation.

One of two aims that presented article has to achieve is a trial of exemplification of qualitative and quantitative approaches complementation. First mentioned trend - the qualitative one - is provided by a study that was conducted for my master thesis entitled 'The quality of life of homosexual women - cases study ${ }^{1}$ '; the second - the quantitative one - is presented by a publication 'The social situation of LGBTA individuals in Poland. Report 2015-2016' which was written as an initiative of three organizations connected to LGBTQIA environments which are: Kampania Przeciw Homofobii ${ }^{2}$, Lambda Warszawa ${ }^{3}$ and Trans-Fuzja ${ }^{4}$.

Another, minor, aim of the article is a renew outlining of the nature of individual and social functioning of homosexual women that bases on conclusions from mentioned publication and from the study that was conducted by me.

Both presented aspirations will be pursued simultaneously because the cognitive nature of the paper is less important than its second aim - results of both studies were shown in separate publications to a great extent (Świder, Winiewski, 2017; Dziarnowska, 2016a; Dziarnowska, 2016b; Piksa ${ }^{5}$, 2016) - its main task is to picture the possibility of coexistence and overlapping of qualitative and quantitative research trends.

${ }^{1}$ Master thesis written under the direction of Tomasz Bajkowski PhD.

${ }^{2}$ A non-governmental organization established in 2001. It tries to work against violence and discrimination towards non-heteronormative individuals. By fulfilling its mission the activists engage themselves into: political, social and legal advocacy, education and forming allied movement. Source: https://kph.org.pl.

${ }^{3}$ An Association established in 1997 in Warsaw. The aim of people who are engaged in its activity is to help individuals who are in a difficult situation because of their sexual orientation and identity. Pledge a safe space to build a positive LGBTQ identity and provide expert help to those in need are the mission of the association. Source: http://lambdawarszawa.org.

${ }^{4}$ A non-governmental organization established in 2008 that works for transsexual individuals' rights. The mission of the organization concerns four aspects: legal advocacy (the analysis of legal conditions in a range of practices and regulations pertaining transsexual individuals), support (support groups, psychological support, social meetings), education (workshops in a range of transsexuality), cultural activity (organizing and promoting cultural events that are friendly to transsexual individuals). Source: http://fundacja.transfuzja.org.

5 The maiden name of the author of the article. 


\section{Methodological assumptions and independent variables of analyzed studies}

A study that was created for the LGBTQIA organizations' publication was conducted from November 2016 to February 2017 (Świder, Winiewski, 2017: 14). Respondents (as assumed: homosexual, bisexual, transsexual and asexual individuals) were asked about their experiences and situation over the course of 20152016. Data was gathered with a questionnaire distributed in the Internet portals connected to issues of mentioned groups; afterwards it was described statistically (Świder, Winiewski, 2017: 13-14). Questions concluded in the questionnaire covered a thematic range as follows: health, employment, education, family life, violence and discrimination, psychic welfare, socio-political believes and relationships approaches.

While studying groups that are socially sensitive, endangered to stigmatization, sampling is usually a problematic question. As authors of the paper underlined, such a situation also took place during their research, because it is difficult to state the sample which covers the representativeness of the results while there is no data defining the number of non-heterenormative individuals in Poland (Świder, Winiewski, 201714-18). What is more, due to the way and the 'places' where the questionnaire was distributed (thematic Internet portals) people who have taken part in the research in the majority were young and to some extent they were involved in a social life of their minority group - hence there is another doubt about the question of validity in results generalization to the whole LGBTQIA community. Nevertheless, as the authors of the report underlined, despite of all mentioned constrains the publication is one of the most extensive and one the most systematized analyzes of the social situation of non-heterosexual individuals. The research encompassed 9660 people, $17,2 \%$ of them were lesbians; age average of the respondents was 25,28, a median was 23 years (Świder, Winiewski, 2017: 17).

The qualitative perspective, to which I am referring report's data, was used in a study that was conducted at the turn of 2014 and 2015 (Piksa, 2015). My interlocutors were eight homosexual women aged from 19 to 40 years old - these extreme values were represented by two of them, the rest (six) were women being 21-24 years old. A purposive sampling (Kubinowski, 2010: 278-282) was supported with a snowball strategy - following interlocutors were pointed out by previous ones until researched categories were theoretically saturated (Flick, 2012: 61).

A research method which I used was an instrumental cases study in a group variation (cited in Kubinowski, 2010: 172), applied technique was a directed freeform interview (Konecki, 2000: 169-170) and the main tool posed interview dis- 
posals that were distinguished on a basis of previously made thematic-notions frame $^{6}$. General categories underlying the research were (Piksa, 2015): physical health, social life, mental condition, interpersonal relationships, environmental aspects, financial status (within mentioned aspects there also were many subcategories).

Gathered data was factually coded (Kubinowski, 2010: 235) and the next step was to analyze it with two methods - the content analysis and the method of constant comparing (Kubinowski, 2010: 246-250).

Correlating both of mentioned studies shows that there are relatively many similar features despite their conceptions were made independently and without a researchers' awarness of the other one existence. Over the article I am referring to the situation of homosexual women because they are the group that is a common sampling link in analyzed papers.

In spite of a high similarity of independent variables encompassed in both studies not all of them can be compared - some categories were not distincted as those relating to non-heteronormative women.

The vast majority of report's respondents and my interlocutors were at a similar age - the average age of those first mentioned was 24,03 (Świder, Winiewski, 2017: 18); using that statistical operation in a relation to a group that I researched it can be said that their average age was 24,87 (Piksa, 2015: 100-105). That category is the first thanks to which one can assume that participants of both studies create a homogenous group. Similar age and the fact that they agreed to fulfil the questionnaire/to take part in an interview ${ }^{7}$ indicate that they are individuals with specific values, believes and opinions about the issues of being a member of a non-heteronormative society.

Another independent variable that lets making comparisons is education of researched women. Report's respondents finished averagely 14,16 years of education (Świder, Winiewski, 2017: 21), that value for my interlocutors was 15 years (Piksa, 2015: 100-105). Mentioned numbers suggest that most of the participants of both studies were students of universities so there is a great chance that they had similar social and intellectual experiences in a range of education.

\footnotetext{
${ }^{6}$ I also asked my interlocutors for completing a series of sentences and I offered them to fulfil a particular SWOT analysis where I asked about strength and weaknesses (relating to the present), chances and threats (relating to the future) connected to their quality of life in the context of being a homosexual woman.

${ }^{7}$ It is worth to underline that these activities are related to a very sensitive and often very intimate areas.
} 
Time lapse of both studies also should be noticed. A common element is a year of 2015. Even though work over my project has begun a bit earlier and acts connected to LGBTQIA organizations' report have finished later, both studies were done in a similar social, cultural and political conditions. Despite governmental change in Poland in 2015 no formal solutions for non-heterosexual individuals/ relationships were implemented, so it can be assumed that the difference in the period of conducting studies is irrelevant for their results.

Independent variables which cannot be compared are: incomes, subjective evaluation of financial situation, place of living and migrations (Świder, Winiewski, 2017: 22-29). These questions also appeared in my study but report's lack of contradistinction for data relating to homosexual women and the fact that not all of my interlocutors referred to some of the aspects specifically (e.g. income) make accurate comparison of studies' results impossible (Piksa, 2015: 100-105, 186-190).

\section{Common categories}

Presented part of the article shows similar or same categories of both analyzed research projects. I mention only those that appeared also during my study so that they can be compared. It is also very important if the authors of the report featured results related to lesbians. The starting point are results presented in the quantitative publication so following report's dependent variables are compared to issues of the thematic-notions frame made for my master thesis.

\section{Public institutions}

The LGBTQIA organizations' publication starts the proper analysis and results' interpretation with a chapter titled 'Trust towards institutions and parliamentary election participation'. Respondents were asked about their attitude towards the government, the parliament, the Police, courts, LGBTQIA organizations (Świder, Winiewski, 2017: 31) and if they took part in the parliamentary election in autumn 2015 (Świder, Winiewski, 2017: 38). The authors of the research showed that non-heteronormative individuals that were studied are mostly mistrustful towards government and parliament, towards police and courts they are mistrustful and trustful to the same extent and LGBTQIA organizations are granted with trust in majority (Świder, Winiewski, 2017: 32).

Data referring to homosexual women was distincted in a range of trust towards the government and the parliament and towards organizations supporting 
their rights. Among all of the respondents lesbians were those who as the vast majority mentioned the government and the parliament as institutions that are not worth their trust (Świder, Winiewski, 2017: 32). They also in the greatest extent of all respondents, said that they trust LGBTQIA organizations (Świder, Winiewski, 2017: 37).

The authors of the research did not distinguished answers of the group of interest in a relation to other mentioned institutions and to election because data representing homosexual women did not reach an extreme value.

The thematic-notions frame of the qualitative project considered a category described as 'political situation in Poland' - in my interlocutors' answers ${ }^{8}$ it appeared mainly as a comment about the government and the parliament of that time. I believe that gathered data can be referred to the report's chapter presented above because the satisfaction with Polish political scene or its lack is connected to trust towards political institutions.

Homosexual women are disappointed with conducted politics; one of them said that political system existing in Poland is disadvantageous and the improvement of country's situation should be started by changing it (Piksa, 2015: 190196).

Statements about LGBTQIA organizations appeared in narrations of two interlocutors even though that question was not encompassed in the research conception. These women pledged cooperation with Lambda Warszawa so it can be assumed that they trust mentioned institution (Piksa: 153).

Data included in the report and that gathered in my study can be described as analogous. Despite the fact that I did not ask my interlocutors just the same questions the narration that some of them have undertaken suggests that they have limited trust toward national institutions and they do trust organizations that support non-heteronormative individuals. The fact that only three of the interlocutors have commented that question is a result of the open form of the interview in which I did not imposed the necessity to answer particular questions; I believe that if I had offered each of them the questionnaire, their answers would be just the same with those given by report's respondents.

\section{Sexual orientation openness}

'Outing and worse treating' is the following chapter of the publication to which I am relating qualitative data. The issues of sexual orientation or sexual identity

\footnotetext{
8 Three of them commented that topic, the rest of them avoided the answer or said that the political scene does not interest them so they do not have an opinion.
} 
openness in different environments of respondents functioning was risen in the paper. Results showing the situation of homosexual women are following:

a) awareness of sexual orientation of researched women have (Świder, Winiewski, 2017: 41): $97 \%$ of friends, $82,9 \%$ of co-workers/school friends, $75,5 \%$ of family members, $29,7 \%$ of neighbours;

b) sexual orientation of respondents is open to (Świder, Winiewski, 2017: 44): $67,8 \%$ of mothers, $51,2 \%$ of fathers, $64,7 \%$ of sisters, $57,8 \%$ of brothers;

c) full acceptation of homosexuality show (Świder, Winiewski, 2017: 47): $37,5 \%$ of mothers, $28,1 \%$ of fathers, $23,1 \%$ of sisters, $21,8 \%$ of brothers;

d) from January 2015 to the moment of study participation $71 \%$ of researched women hid their sexual orientation at work place, $73,2 \%$ at universities and $50 \%$ of them did not reveal it for their neighbours, landlords or lessee (Świder, Winiewski, 2017: 51);

e) in an immediate contact with Church/religious association representatives 63,8\% of lesbians were unequally treated (Świder, Winiewski, 2017: 52).

Gathered qualitative data that gives a possibility of comparing to results presented above is included in a range of three thematic-notions categories: interpersonal relations (openness of sexual orientation and its acceptance), social contacts (functioning as a homosexual at work, at university, at neighbourhood) and mental condition (issues of religiousness and contact with clerics).

Instead of taking a stance on each of points mentioned above I would like to link owned data into thematic groups. First of all, I am going to conduct a simultaneous analysis of questions connected to coming out and family acceptance. Referring to that community it should be underlined how important is sampling on the way of results interpretation. Qualitative data change, gathered in a range of only eight cases, into their percentage equivalents deprives them context (the real composition of the family) which is essential to understand their interpersonal relations. I am going to show shortly that context so that make it possible to illustrate mentioned data in a comparison with quantitative research.

Approximately $70 \%$ of family members of my interlocutors know that they are not heteronormative (Piksa, 2015: 141-152). Each of researched women had a mother and five of them came out as lesbians to them (around 63\%) - two among five mothers accepted their daughters' sexual orientation unconditional-

\footnotetext{
${ }^{9}$ In the LGBTQIA organizations report there are data relating to: clients at work, immediate supervisors, medical staff, public places and institutions, loved ones loss. What is more, in some questions the authors of the study distincted detailed percentage contribution of some aspects in respondents answers; these also are not presented because of a lack of their reflection in qualitative data that I own.
} 
ly (around 40\%). Fathers were present in a half of the families, 75\% of them knew about interlocutors' non-heteronormativity but non of them accepted it. Four studied women had sisters which experienced the coming out in $100 \%$ - one of them did not approve that fact ( $75 \%$ of them embraced their sister's sexual orientation). Three interlocutors pledged to have a brother from who only one knows about homosexuality (aroud 33\%) and accept it fully (100\%).

Comparing data from the quantitative research with these presented above that comes from qualitative material one can notice single similarities - the percent of family members knowing about sexual orientation of researched women and information referring to their mothers. It must be underlined that the family composition is an independent variable, so as I mentioned before, the context is indispensible because it lets to understand family relations' complexity. Instead of further comparisons I would like to use that considerations as an example of the necessity of complimentary treating both analyzed trends in scientific research conducting so as to fully understand interesting phenomenon.

Referring to following questions it should be noticed that my interlocutors pledged a high level of their sexual orientation openness among their friends (Piksa: 158-162). Only one of them had not come out to all of her friends because of the fact that she comes from a very conservative environment and she was afraid of their reaction (Piksa: 160).

Coming out towards immediate co-workers/co-students was done by the vast majority of studied women; they were not open about their sexuality in situations when their relations with others were not close enough to talk about sexual orientation (Piksa: 158-162). Five of my interlocutors (around 65\%) happened to hide homosexuality at work place/place of education on purpose; such acts they usually justified with their knowledge about others' homophobic opinions or with co-working with older generation, which in their opinion, could not understand the issue of non-heteronormativity.

The category of relations with neighbourhood was only desultory described by researched women - four of them pledged that they do not have any contact with their neighbours and they also think that their homosexuality is not open to them (Piksa: 158-162). Two of them have neighbourhood relations with single individuals and they openly speak about their sexual orientation. I do not own data relating to openness/hiding of being a lesbian towards landlords/lessee.

The last question that needs to be referred to in a range of analyzed report's chapter is making a contact with clerics and the process of that relation taking into consideration homosexuality. Non of the women pledged a face-to-face conversa- 
tion with Church ${ }^{10}$ representatives about sexual orientation. Seven of them have an opinion about clerics' non-heteronormativity acceptance, or should I rather say, about its lack what for my interlocutors is incompatible with preached idea of compassion (Piksa: 135-140). Their notion about negative opinion of that environment towards LGBT individuals is taken from church sermons, narration in media and their non-heteronormative friends' stories.

Comparing report's data and qualitative research data relating to issues of the circle of friends, co-workers/co-students, neighbourhood and the contact with clerics, the results convergence can be noticed. Respondents of the report and my interlocutors came out to almost all of their friends. In a methodological part of the paper I mentioned that the age average of both groups of researched women is around 24-25 years; one can assume that their friends circle is also at a similar age. Supposably, youth in a broad sense, functioning in the Internet and being an active member of so called global village can generate a higher openness also in a range of non-heteronormativity acceptance - homosexuality exposure in almost $100 \%$ is not surprising in the face of determinants mentioned above.

Coming out to co-workers/co-students and a necessity to hide the sexual orientation had also a very similar results in both studies. Despite that fact, I believe that such a convergence can be true or false to the same extent. That is an another results' example where the lack of the context is peculiarly disadvantageous ${ }^{11}$. As I mentioned above, my interlocutors' motives of not being open with their sexual orientation are very different - not in every case the reason was a homophobic fear. Results of the quantitative research do not show causes of using these strategies so that in that question they do not fulfil the aim of sociological and psychological deepen analysis of LGBTQIA individuals' living conditions in Poland (Świder, Winiewski, 2017: 15).

Openness of sexual orientation and its acceptance in a range of neighbourhood relations is also a very complex category. Two of my interlocutors pledged coming out to single neighbours but they had done it only because they have deepen relationships with these people. Homosexuality and heterosexuality (presupposed) are not questions that are discussed with people met randomly and occasionally.

${ }^{10}$ I omit representatives of religious associations because each of researched women was baptized and was raised as a catholic.

${ }^{11}$ Comparing that case to those presented above referring to the circle of friends it should be noticed that the circle is not 'imposed' in contrary to co-workers and co-students. It can be assumed that LGBT individuals will look for friends belonging to the same environment or these who will accept them - such a conclusion draws the context of my results' interpretation. Relations at work and at place of education are conditioned by more complex factors. 
Especially taking into consideration existing socio-cultural determinants when the neighbourhood institution is not as important to the individual as it used to be (Pięta, 2014: 233). Results of the quantitative research do not examine the issue of studied women familiarity with their neighbours so that they do not picture reasons of the lack of sexual orientation openness toward them.

The last category that need to be compared is a relation with Church/religious associations representatives. The report treats about direct negative contact and such a situation applied to $63,8 \%$ of lesbians. My interlocutors underlined that they never were personally badly treated and their notions are the results of overheard situations. Despite that difference both results can be estimated as similar - frequent unfavourable clerics' statements towards non-heteronormativity are facts ${ }^{12}$, even though Pope Francis himself said in 2013: 'If they accept the Lord and have goodwill, who am I to judge them? (...)'. Although, the head of the Roman Catholic Church took on a less conservative stand, a lot of its representatives do not want to accept it (Dziarnowska, 2016a: 122-126). It is worth to underline acts of 'Wiara i Tęcza' organization which unites non-heteronormative individuals and clerics who are favourable to them so that they can fulfil spiritual needs in a friendly environment - my interlocutors showed that association as a hope for Church in Poland.

III. The evaluation of life until now, sense of isolation and ways of coping with stress

Categories listed in a heading were gathered in a following report's chapter ${ }^{13}$. Referring to the first of them it should be noticed that homosexual women while evaluating their life until now in $68 \%$ described it in a positive dimension, $15,5 \%$ of them commented it neutrally and 16,4\% negatively (Świder, Winiewski, 2017: 58).

Over a half of respondents $(53,1 \%)$ declares that they have the sense of isolation (Świder, Winiewski, 2017: 59).

The researchers distinguished a group of ways of coping with difficult situations that homosexual use, these are (Świder, Winiewski, 2017: 64): doing distracting things (34,8\%), asking for advice and help (32,5\%), mobilization and acting

${ }_{12}$ Texts published in a magazine 'Miłujcie się' can be an example. They describe homosexuality in an uncompromised and highly negative way. It is often defined as denaturalization, a source of suffering or even it is put on a par with zoophile.

${ }_{13}$ Apart from showed issues, that and the next chapter focus also on: suicidal thoughts, current health condition, symptoms of depression. I do not take up description of these results because of a lack of distinction to those connected to lesbians or because the study did not encompassed some aspects in its thematic-notions frame. 
$(29,9 \%)$, cheering up that it could be worse or that other people are in a worse position (17,2\%), giving up and acting resignation (13\%), drinking alcohol (10,4\%), using tranquilizers $(5,4 \%)$, praying to God for help $(4,9 \%)$.

Overall evaluation of life until now was described by my interlocutors in the very beginning of each interview. While starting researching each case I asked the woman: 'How do you evaluate the quality of your life?'. The empirical material gathered as an answer to that question and also the whole narration of interlocutors picture their lives' satisfaction. The half of women commented that topic positively, three of them rather neutrally, one rather negatively. Results of both studies are similar in a range of respondents and interlocutors content with their functioning - women researched by me, which I count to that group, underlined their satisfaction. Those I signed to other two categories did not pledged the extent of their satisfaction - defining its level is my interpretation of their whole narration. It is difficult to compare those results to the quantitative study - a very interesting thing would be a compilation of both approaches in which the qualitative narration, done here, relate to unambiguous choice in a questionnaire.

Six of my interlocutors felt isolated or was afraid of such condition (Piksa, 2015: 112-120). That issue appeared in the context of diagnosing fear sources of researched women. Presented results are analogues with report's data. It can be suspected that non-heteronormativity generates a bigger threat of loneliness. As my interlocutors underlined, their fear connected to being isolated has three-fold source. It is provided by messages coming from the family of origin which does not accept homosexuality, by homophobic living environment and also by personal experiences - studied women underlined that it is difficult to find an appropriate romantic partner.

Applying to the last described question - the strategy of coping with difficult situations - it should be mentioned that my interlocutors pledged fulfilling two of ways listed previously ${ }^{14}$ : giving up (one woman) and mobilization (four women) (Piksa: 112-120). It is worth to stress that the one who said that she resigns acting does that only in a one situation which is not connected to homosexuality and in other positions she mobilizes. The strategy applying to most of my interlocutors places itself on a third position in the report but taking into consideration precise percentage data I would like to notice that there is a little difference in results between those from the first, the second and the fourth place. I believe that the fact

${ }^{14}$ I did not particularly ask about coping in difficult situations but that aspect appeared in a range of comments about stress and methods of dealing with it. I believe that these two categories can be recognized as unambiguous. 
of taking part in a research conducted with the interview method (which is long and exhausting) and pertaining very delicate issues is an evidence of tendency to taking up challenges.

\section{Violence motivated by prejudices}

In the report an analyzed category is understood as hurting somebody physically/mentally and also as passive acts (e.g. ignoring, services refusing) (Świder, Winiewski, 2017: 75). To a little extent I can apply result of my study to these contained in the report ${ }^{15}$. I did not deal with the issue of violence particularly because of the fact that during interviews my interlocutors did not indicate that such a problem applies to them. The only indicator that I have data about is the percent of the respondents experiencing verbal violence. Information about insults addressed towards them appeared in a narration connected to the quality of their functioning as a lesbian in a social space. In the report it is said that $64,12 \%$ researched lesbians experienced such acts from 2015-2016 (Świder, Winiewski, 2017: 81). Over a half of my interlocutors also was endangered on verbal violence motivated by homophobia (Piksa, 2015: 176-184). It can be assumed that there is a correlation between exposure on acts of violence and sexual orientation openness in group of their functioning (these results correspond with conclusions presented in the second point of this paper). What is more, they experience verbal violence in public places when they suggest not to be heterosexual by their behaviour and appearance (Piksa: 184-185).

\section{Family life}

Another chapter of the report is about both current romantic relationship of homosexual women and their opinions connected to family life in a broad sense. At the moment of conducting the research $63,8 \%$ women were in same-sex relationships (Świder, Winiewski, 2017: 89) ${ }^{16}$. When asked if in Poland there was a possibility to reach a partner relationship would they use such a solution, 92,2\%

${ }^{15}$ Another issues brought up in analyzed chapter: percentage of people experiencing different kinds of violence (sexual violence, physical violence, vandalism, refusing and threats), an average number of violence acts divided into counties, places where acts of aggression happen, profiles of attacks causers. In the report there also exist individual two chapters connected to that issue. One of them focuses on hate speech, the second is about minority stress. I am not going to refer to it in this paper because of the lack of results providing the possibility to make comparisons. I also omit the part about LGBT school youth and non-heterosexual women' incomes - the report does not distinguish results to the lesbian group.

${ }^{16}$ According to the lesbian stereotype - appearance, the way of dressing up and moving resembling a man. 
answered 'yes'; 72,2\% would like to get married and 44,5\% would decide to adopt children (Świder, Winiewski, 2017: 91).

Most of homosexual women I talked to, at the moment of the interview were not in a relationship, but three of them pledged that they split up not a long time ago (Piksa, 2015: 153-158).

Interlocutors were asked what they think about same-sex legal partner/marital relationships and about children adoption by non-heteronormative homosexuals. Despite that the question did not refer to them indirectly, the vast majority interpreted it as their desire to do so (Piksa, 2015: 176-183). Results that I gathered are very up-close to those presented by the report. Six of my interlocutors would like to be in a partner relationships, one would like to form such a relation too or get married and five of them would adopt a child. That question contained in the questionnaire gave a possibility of multiple choice, probably that why respondents exhibited a high level of choices in a range of partner and marital relationship. I do not question each of my interlocutors about these two variants and they talked about partner relationship more often, probably because the public discussion in Poland is connected primarily to that option.

Table. 1 Synthetic comparison of analysed

\begin{tabular}{|c|c|c|c|}
\hline & & $\begin{array}{c}\text { LGBTQIA } \\
\text { ORGANIZATIONS' REPORT }\end{array}$ & AUTHOR'S STUDY' ${ }^{17}$ \\
\hline \multirow{5}{*}{ 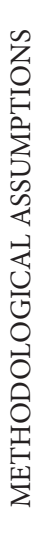 } & Research perspective & Quantitative & Qualitative \\
\hline & $\begin{array}{l}\text { Research } \\
\text { methods; } \\
\text { techniques; } \\
\text { tools }\end{array}$ & $\begin{array}{l}\text { Diagnostic poll method; } \\
\text { questionnaire; questionnaire } \\
\text { survey }\end{array}$ & $\begin{array}{l}\text { Cases study; directed free- } \\
\text { form interview; interview } \\
\text { disposals and thematic-notion } \\
\text { frame }\end{array}$ \\
\hline & Data analysis methods & Statistical analysis & $\begin{array}{l}\text { Content analysis, constant } \\
\text { comparing method }\end{array}$ \\
\hline & Sample & $\begin{array}{l}\text { Users of LGBTQIA Internet } \\
\text { portals, about } 1660 \text { lesbians }\end{array}$ & $\begin{array}{l}\text { Purposive sampling, snowball } \\
\text { strategy, } 8 \text { lesbians }\end{array}$ \\
\hline & Period of time & $\begin{array}{l}\text { Years of } 2016 \text { and } 2017 \text {, } \\
\text { questionnaire questions were } \\
\text { connected to experiences from } \\
2015 \text { and } 2016\end{array}$ & Years of 2014 and 2015 \\
\hline
\end{tabular}

${ }_{17}$ The context of data presented in a proprietary qualitative study was described throughout previous parts of the article. 


\begin{tabular}{|c|c|c|c|c|}
\hline & Individual & Age average & 24,03 years & 24,87 years \\
\hline & & $\begin{array}{l}\text { Years of educa- } \\
\text { tion average }\end{array}$ & 15,16 years & 15 years \\
\hline \multirow{6}{*}{ 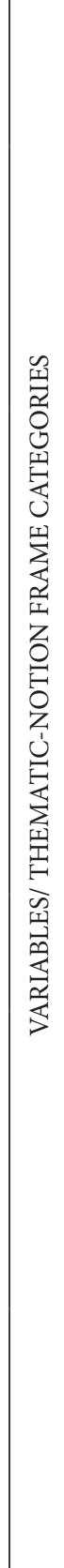 } & $\begin{array}{l}\text { Public } \\
\text { institutions }\end{array}$ & $\begin{array}{l}\text { Trust toward } \\
\text { government and } \\
\text { parliament }\end{array}$ & $\begin{array}{l}\text { The vast majority of re- } \\
\text { searched homosexual women } \\
\text { found government and parlia- } \\
\text { ment not worth to trust }\end{array}$ & $\begin{array}{l}\text { All of researched homosexual } \\
\text { women have limited trust } \\
\text { towards public institutions }\end{array}$ \\
\hline & & $\begin{array}{l}\text { Trust toward } \\
\text { LGBTQIA } \\
\text { organizations }\end{array}$ & $\begin{array}{l}\text { Researched homosexual wom- } \\
\text { en trust LGBTQIA organiza- } \\
\text { tions to the greatest extent }\end{array}$ & $\begin{array}{l}\text { Three of researched homosex- } \\
\text { ual women trust LGBTQIA } \\
\text { organizations; the rest of them } \\
\text { do not speak about interesting } \\
\text { problem, because it was not } \\
\text { included in the thematic-no- } \\
\text { tion frame }\end{array}$ \\
\hline & $\begin{array}{l}\text { Sexual } \\
\text { orientation } \\
\text { openness }\end{array}$ & Family of origin & $\begin{array}{l}\text { Awareness of homosexual ori- } \\
\text { entation of respondents have: } \\
75,5 \% \text { of family; } \\
67,8 \% \text { of mothers; } \\
51,2 \% \text { of fathers; } \\
64,7 \% \text { of sisters; } \\
57,8 \% \text { of brothers; } \\
\text { Full acceptation of respond- } \\
\text { ents' homosexuality show: } \\
37,5 \% \text { of mothers; } \\
28,1 \% \text { of fathers; } \\
23,1 \% \text { of sisters; } \\
21,8 \% \text { of brothers }\end{array}$ & $\begin{array}{l}\text { Awareness of homosexual ori- } \\
\text { entation of interlocutors have: } \\
\text { about } 70 \% \text { of family; } \\
63 \% \text { of mothers; } \\
75 \% \text { of fathers; } \\
100 \% \text { of sisters; } \\
\text { about } 33 \% \text { of brothers } \\
\text { Full acceptation of interlocu- } \\
\text { tors homosexuality show: } \\
\text { about } 40 \% \text { of mothers; } \\
0 \% \text { of fathers; } \\
75 \% \text { of sisters; } \\
100 \% \text { of brothers }\end{array}$ \\
\hline & & Friends & $\begin{array}{l}\text { Awareness of homosexual ori- } \\
\text { entation of respondents have } \\
97 \% \text { of their friends }\end{array}$ & $\begin{array}{l}\text { Awareness of homosexual ori- } \\
\text { entation of interlocutors have } \\
87,5 \% \text { of their friends }\end{array}$ \\
\hline & & $\begin{array}{l}\text { Co-workers/ } \\
\text { co-students }\end{array}$ & $\begin{array}{l}\text { Awareness of homosexual } \\
\text { orientation of respondents } \\
\text { have } 97 \% \text { of their co-workers/ } \\
\text { co-students; about } 71 \%-73,2 \% \\
\text { of researched women used to } \\
\text { hide their sexual orientation at } \\
\text { work/ at place of education }\end{array}$ & $\begin{array}{l}\text { Awareness of homosexual } \\
\text { orientation of interlocutors } \\
\text { have the vast majority of their } \\
\text { co-workers/ co-students; } \\
\text { about } 65 \% \text { of researched wom- } \\
\text { en used to hide their sexual } \\
\text { orientation at work/ at place of } \\
\text { education }\end{array}$ \\
\hline & & $\begin{array}{l}\text { Neigh- } \\
\text { bour-hood }\end{array}$ & $\begin{array}{l}\text { Awareness of homosexual ori- } \\
\text { entation of respondents have } \\
29,7 \% \text { of their neighbours; } \\
50 \% \text { of respondents purposely } \\
\text { hide homosexuality }\end{array}$ & $\begin{array}{l}\text { Most of interlocutors declare } \\
\text { no contact with neighbours } \\
\text { and probable secrecy of their } \\
\text { sexual orientation; two of } \\
\text { them who are in a relation } \\
\text { with neighbours have come } \\
\text { out }\end{array}$ \\
\hline
\end{tabular}




\begin{tabular}{|c|c|c|c|c|}
\hline & & Clerics & $\begin{array}{l}\text { In an immediate contact with } \\
\text { clerics } 63,8 \% \text { respondents } \\
\text { were unequally treated }\end{array}$ & $\begin{array}{l}\text { Non of the interlocutors } \\
\text { declare an immediate negative } \\
\text { relation with clerics; their } \\
\text { statements are connected to } \\
\text { inequalities met during church } \\
\text { sermons, narration in media } \\
\text { and their non-heteronorma- } \\
\text { tive friends' stories. }\end{array}$ \\
\hline & \multicolumn{2}{|c|}{ Life evaluation } & $\begin{array}{l}\text { Respondents estimated their } \\
\text { life until now as: positive: } 68 \% \\
\text { of respondents } \\
\text { neutral: } 15,5 \% \text { of respondents; } \\
\text { negative: } 16,4 \% \text { of respondents }\end{array}$ & $\begin{array}{l}\text { Interlocutors estimated their } \\
\text { life until now as:- positive: } \\
50 \% \text { of interlocutors; } \\
\text { neutral: } 37,5 \% \text { of interlocutors; } \\
\text { negative: } 12,5 \% \text { of interlocutors }\end{array}$ \\
\hline 學 & \multicolumn{2}{|c|}{ Sense of isolation } & $\begin{array}{l}53,1 \% \text { of respondents declare } \\
\text { having the sense of isolation }\end{array}$ & $\begin{array}{l}75 \% \text { of interlocutors declare } \\
\text { having the sense of isolation }\end{array}$ \\
\hline 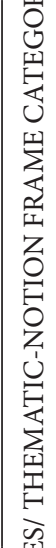 & \multicolumn{2}{|c|}{ Ways of coping with stress } & $\begin{array}{l}\text { Respondents' ways of coping } \\
\text { with difficult situations: } \\
34,8 \% \text { doing distracting things; } \\
32,5 \% \text { asking for advise and } \\
\text { help; } \\
29,9 \% \text { mobilization and acting; } \\
17,2 \% \text { cheering up it could be } \\
\text { worse or that other people are } \\
\text { in a worse position; } \\
13 \% \text { giving up and acting } \\
\text { resignation; } \\
10,4 \% \text { drinking alcohol and } \\
5,4 \% \text { using tranquilizers; } \\
\text { 4,9\% praying to God for help }\end{array}$ & $\begin{array}{l}\text { Interlocutors' ways of coping } \\
\text { with difficult situations: } \\
50 \% \text { mobilization and acting; } \\
12,5 \% \text { giving up and acting } \\
\text { resignation }\end{array}$ \\
\hline 学 & \multicolumn{2}{|c|}{$\begin{array}{l}\text { Violence motivated by preju- } \\
\text { dices }\end{array}$} & $\begin{array}{l}\text { Verbal violence touched } \\
64,12 \% \text { of respondents }\end{array}$ & $\begin{array}{l}\text { Verbal violence touched more } \\
\text { than } 50 \% \text { of interlocutors }\end{array}$ \\
\hline & \multirow[t]{2}{*}{ Family life } & $\begin{array}{l}\text { Being } \\
\text { in a relationship }\end{array}$ & $\begin{array}{l}\text { Same-sex relationship was made } \\
\text { by } 63,8 \% \text { of respondents at the } \\
\text { moment of conducting the study }\end{array}$ & $\begin{array}{l}\text { Most of researched wom- } \\
\text { en were not in a same-sex } \\
\text { relationship at the moment of } \\
\text { conducting the study }\end{array}$ \\
\hline & & $\begin{array}{l}\text { Attitude toward } \\
\text { formal solutions }\end{array}$ & $\begin{array}{l}\text { In a case of having a law } \\
\text { letting to adopt children and } \\
\text { to formalize relationships of } \\
\text { homosexuals: } \\
\text { - } 92,2 \% \text { of respondents would } \\
\text { like to formalize their rela- } \\
\text { tionship; } \\
-72,2 \% \text { of respondents would } \\
\text { like to get married; } \\
-44,5 \% \text { of respondents would } \\
\text { like to adopt children }\end{array}$ & $\begin{array}{l}\text { In a case of having a law } \\
\text { letting to adopt children and } \\
\text { to formalize relationships of } \\
\text { homosexuals: } \\
-75 \% \text { of interlocutors would } \\
\text { like to formalize their rela- } \\
\text { tionship; } \\
-12,5 \% \text { of interlocutors } \\
\text { would like to get married; } \\
-62,5 \% \text { of interlocutors } \\
\text { would like to adopt children }\end{array}$ \\
\hline
\end{tabular}

Source: own elaboration. 


\section{Results and summary}

Information gathered in the article should be summed up on two levels as two-dimensionally its aims were formed.

Applying to cognitive issues of both studies it is worth to underline the difficult situation of homosexual women. Frequent lack of homosexual orientation' acceptance and the necessity to hide it in many environments of functioning leads to sense of isolation. The absence of legal solutions giving a possibility to formalize a relationship and to adopt children and a lack of Polish government acts in that range, makes that homosexual women do not trust public institutions and consequently they do worry about their future.

The second task of the article was to show possibilities of qualitative and quantitative research supplementing. The subject literature related to connecting both approaches says that results of both studies can (cited in Flick, 2011: 168): be convergent (totally or to a great extent coherent), fulfil each other (interviews deepen and provide details of some issues). In a vast majority results of both analyzed projects reflect each other. What is more, by interpreting those convergences I frequently pictured my interlocutors' statements which gave the context to some questions, explained and widen the analysis.

I believe that triangulation, facilitation and complementarity mentioned in the very beginning had application in linking both studies. Presented conceptions verify analysis and interpretation accuracy of gathered empirical material. Dependent variables showed in the questionnaire can be reflected in the thematic-notions frame of the qualitative study what will replenish it with issues yet unidentified (a group of such aspects was shown in references). On the other hand, deriving from the mentioned thematic-notions frame, the quantitative study could be built up with categories providing information about interpersonal relations what would outline the context of some answers (e.g. the issue of coming out to neighbours). The fact that both studies fulfilled the condition of complementarity I justified above - qualitative and quantitative data was a mutual replenishment.

Finalizing my consideration I would like to once again underline the fact that both projects were made independently. In spite of a lack of researchers cooperation they characterize with many similarities in a range of categories that underlain the research and as the effect - a high extent of the results' mutual reflection. Common formulation of eclectic research conception would give the possibility of deepen and more comprehensive analysis and interpretation of social situation and the quality of life of LGBTQIA society members. Such diagnosis would lead to a greater awareness of complexity of interesting phenomenon and emerging from it - both efficiency and effectiveness in designing actions for non-heteronormative individuals. 


\section{Bibliography}

Dziarnowska M. (2016a). Kościót, polityka, warunki życia - źródła irytacji homoseksualnych kobiet. „Parezja” no. 2/2016.

Dziarnowska M. (2016b). Relacje homoseksualnych kobiet z rodzina pochodzenia jako czynnik warunkujący jakość ich życia. 'Kultura - Społeczeństwo - Edukacja' no. 1/2016.

Flick U. (2011). Jakość w badaniach jakościowych. Trans. P. Tomanek. Warszawa.

Flick U. (2012). Projektowanie badania jakościowego. Trans. P. Tomanek. Warszawa.

Hammersley M. (2013). The relationship between qualitative and quantitative research: paradigm loyalty versus methodological eclecticism. https://martynhammersley.files.wordpress.com/2013/03/ relationship-between-qualitative-and-quantitative-research.pdf, access: 29.01.2018.

Konecki K. (2000). Studia z metodologii badan jakościowych. Teoria ugruntowana. Warszawa.

Kubinowski D. (2010). Jakościowe badania pedagogiczne: filozofia, metodyka, ewaluacja. Lublin.

Pięta J. (2014). Pedagogika czasu wolnego. Warszawa.

Piksa M. (2015). Jakość życia homoseksualnych kobiet - studium przypadków, typescript of master thesis. Białystok.

Piksa M. (2016). Quality of Life of Homosexual Women in the Context of Their Functioning in Society - Chosen Aspects. 'Journal of Gender and Power' no. 1/2016.

Silverman D. (2012). Interpretacja danych jakościowych. Trans. M Głowacka-Grajper, J. Ostrowska. Warszawa.

Straś-Romanowska M. (2010). Badania ilościowe vs jakościowe - pytanie o tożsamość w psychologii. 'Roczniki psychologiczne' no. 1/2010.

Świder M., Winiewski M. (ed.). (2017). Sytuacja społeczna osób LGBTA w Polsce. Raport za lata 20152016. Warszawa. 